\title{
PENERAPAN METODE SIMPLE ADDITIVE WEIGHTING (SAW) PADA PENILAIAN KINERJA KARYAWAN DI PT CIRILL INDONESIA
}

\author{
Yunita Fauzia Achmad ${ }^{(1)}$, Ravie Kurnia Laday ${ }^{(2)}$, dan Dannish Apriza Purwa Kusuma ${ }^{\left(\mathbb{D}^{3)}\right.}$ \\ ${ }^{1,3}$ Sistem Informasi, Ilmu Komputer, Universitas Esa Unggul \\ ${ }^{2}$ Teknik Informatika, FTIKV, Insitut Sains dan Teknologi Al-Kamal \\ ${ }^{1,3} \mathrm{Jl}$. Arjuna Utara No 9 Kebon Jeruk, Jakarta, 11510 \\ ${ }^{2}$ Jl. Al -Kamal Raya No. 2 Kebon Jeruk, Jakarta, 11520 \\ E-mail : yunita@esaunggul.ac.id ${ }^{1)}$,ravie.ifista@gmail.com ${ }^{2)}$, dannishapriza@gmail.com ${ }^{3)}$
}

\begin{abstract}
ABSTRAK
Sumber daya manusia (SDM) merupakan bagian yang paling penting di dalam sebuah perusahaan, kinerja karyawan menentukan keberhasilan pada perusahaan, semakin baik kinerja karyawan maka semakin besar keuntungan yang didapatkan oleh perusahaan. Tujuan dari penelitian ini adalah untuk membantu pihak perusahaan terutama bagian HRD dalam melakukan penilaian kinerja karyawan secara terstruktur, tidak bersifat subjektif dan akurat. Metode penelitian ini yang digunakan terdiri dari dua yaitu metode pengambilan data dan metode perhitungan data penilaian kinerja karyawan. Metode pengambilan data terdiri dari teknik wawancara untuk mendapatkan kriteria - kriteria perhitungan data, sedangkan Metode perhitungan data yang digunakan adalah metode Simple Additive Weighting (SAW) yang merupakan salah satu metode sistem pendukung keputusan yang banyak diterapkan di beberapa kasus sistem pendukung keputusan dan kriteria yang digunakan terdiri dari Kehadiran, kerja sama, komitmen, kepemimpinan, ketepatan target kerja, dan sikap atau etika. Kriteria yang digunakan ini didapat dari hasil wawancara penelitian kepada pihak perusahaan, dan referensi dari beberapa jurnal terkait. Metode SAW memiliki beberapa tahapan yang harus dilakukan, diantaranya adalah menghitung data alternatif yang digunakan pada penelitian ini diambil sampel data alternatif sebanyak 10 sampel dengan sistem random sampling, tahap kedua setelah mendapatkan data alternatif dilakukan normalisasi data alternatif berdasarkan kriteria, setelah hasil normalisasi di dapat, tahapan selanjutnya adalah perhitungan pemeringkatan dari setiap data alternatif dan di dapatlah nilai tertinggi sampai terendah dari perhitungan metode SAW. Hasil dari implementasi penelitian ini adalah metode SAW telah berhasil melakukan pemeringkatan dari data alternatif penilaian kinerja karyawan berdasarkan nilai tertinggi yang di dapat dari perhitungan metode SAW.
\end{abstract}

Kata Kunci: Sumber Daya Manusia, Sistem Pendukung Keputusan, Metode Simple Additive Weighting, Kinerja Karyawan

\section{PENDAHULUAN}

PT Cirill Indonesia adalah perusahaan yang bergerak di produksi air minum kemasan dengan nama Cirill. PT Cirill Indonesia memiliki 150 karyawan dan memiliki 8 bagian. Kualitas sumber daya manusia merupakan salah satu faktor penunjang dalam meningkatkan produktivitas kinerja dari suatu perusahaan (Anto, Mustafidah and Suyadi, 2015). Penilaian kinerja karyawan merupakan salah satu alat yang digunakan untuk mengevaluasi pekerjaan masing - masing individu karyawan pada setiap bagian untuk memenuhi standar kinerja yang telah ditetapkan oleh perusahaan (Hardianti $d k k$., 2017)

Saat ini penilaian kinerja karyawan yang dilakukan masih menggunakan prosedur yang berjalan yaitu, melihat rekapitulasi perhitungan kehadiran dan penilaian langsung dari manager pada setiap bagian kepada karyawan, dengan sistem seperti ini menimbulkan beberapa masalah diantaranya menghasilkan penilaian yang subjektif dan terjadi tidak akurat nya dari hasil perhitungan kinerja karyawan. Mengakibatkan penilaian kinerja karyawan tidak lagi objek melainkan subjektif, sehingga menimbulkan ketidakadilan dalam penilaian kinerja karyawan.

Berdasarkan permasalahan yang ada, maka dibutuhkan sebuah perhitungan yang akurat dalam melakukan perhitungan kinerja karyawan. Salah satu metode perhitungan yang banyak digunakan adalah metode SAW (simple additive weighting ).

Metode SAW merupakan salah satu metode sistem pendukung keputusan yang dapat menyelesaikan masalah penyeleksian dalam sistem pengambilan keputusan multi proses. Simple Additive weighting merupakan metode penjumlahan bobot (Waskito, Setya and Daryanto, 2018). Sistem pendukung keputusan adalah suatu sistem informasi berbasis komputer yang mengombinasikan antara model dan data untuk menyediakan dukungan kepada pengambil keputusan dalam memecahkan sebuah masalah (Achmad dan Ladayy 2018) (Sharda, Delen and Turban, 2019).

Penggunaan metode SAW dalam penelitian sistem pendukung keputusan telah banyak dilakukan diantaranya pada penelitian (Masri, 2016) yang menggunakan 4 kriteria yaitu kualitas kerja, disiplin 
kerja, semangat kerja, dan kerja sama. Kemudian penelitian (Sukanto, 2018) penelitian ini dengan menggunakan 5 kriteria yaitu kedisiplinan kerja, pendidikan terakhir, pengalaman kerja, kerja sama, dan keaktifan. Pada penelitian (Anto, Mustafidah and Suyadi, 2015) kriteria yang digunakan terdiri dari 4 kriteria yaitu kehadiran, pendidikan, pengembangan diri, dan penunjang. Terdapat juga pada penelitian (Loekito $d k k$., 2020) yang menggunakan 3 kriteria yaitu sikap, perilaku dan disiplin. Penelitian lain yang terkait adalah penelitian (Warmayudha and Komarudin, 2017) yang menggunakan 7 kriteria pada penilaian kinerja karyawan. Dapat dilihat bahwa setiap penelitian sistem pendukung keputusan dalam penilaian karyawan menggunakan kriteria yang bervariasi dalam pengukurannya. Tetapi pada penelitian tersebut belum ada yang menggunakan kriteria komitmen, kepemimpinan dan ketepatan target kerja.

Berdasarkan wawancara yang dilakukan peneliti kepada pihak manajemen di PT Cirill Indonesia bahwa kriteria tersebut merupakan kriteria yang penting dalam penilaian karyawan, maka pada penelitian ini kriteria yang digunakan untuk mengukur penilaian karyawan bersumber dari internal dan eksternal yaitu dari internal perusahaan yang terdiri dari komitmen, kepemimpinan, dan ketepatan kerja, sedangkan kriteria yang berasal dari eksternal yaitu penelitian - penelitian terkait adalah absensi, kerja sama, dan sikap / etika.

\section{RUANG LINGKUP}

Dalam penelitian ini permasalahan mencakup:

1. Cakupan Permasalahan

Permasalahan yang ada adalah belum adanya sistem pendukung keputusan yang dikembangkan pada PT Cirill Indonesia untuk melakukan penilaian kinerja karyawan

2. Batasan Penelitian

Penelitian ini hanya membahas tentang perhitungan metode SAW dalam melakukan penilaian karyawan dan melakukan pemeringkatan nilai karyawan dari yang terkecil hingga terbesar

3. Rencana Hasil yang didapat

Hasil yang didapat adalah sebuah perhitungan penilaian kinerja karyawan pada sistem pendukung keputusan menggunakan metode SAW yang dapat membantu pihak manajemen PT Cirill Indonesia dalam hal penilaian kinerja karyawan secara otomatis dan membantu pihak manajemen dalam mengambil keputusan karyawan terbaik.

\section{BAHAN DAN METODE}

Berikut ini adalah bahan dan metode yang terkait pada penelitian ini, diantaranya adalah :

\subsection{Metode Pengumpulan Data}

Metode pengumpulan data yang digunakan pada penelitian ini adalah :

1. Wawancara

Tahapan wawancara ini dilakukan untuk mengetahui masalah yang ada, dengan mengajukan beberapa pertanyaan lisan pada pihak terkait untuk mendapatkan data - data yang dibutuhkan oleh peneliti. Wawancara ini dilakukan pada bagian HRD dan pada setiap bagian yang terkait dengan sistem pendukung keputusan kinerja karyawan

2. Observasi

Peneliti melakukan observasi untuk melihat secara langsung cara kerja setiap bagian dan melihat metode yang dilakukan dalam penilaian pada setiap karyawan.

\subsection{Sistem Pendukung Keputusan}

Sistem pendukung keputusan adalah sebuah sistem yang mampu memberikan kemampuan pemecahan masalah dengan kondisi semi terstruktur, dimana tak seorang pun tahu secara pasti bagaimana keputusan harus dibuat. Sistem pendukung keputusan ditujukan untuk mendukung manajemen dalam melakukan pekerjaan yang bersifat analitis dalam situasi yang kurang terstruktur dan kinerja yang kurang jelas (Sharda, Delen and Turban, 2019).

\subsection{Metode SAW (Simple Additive Weighting)}

Metode SAW merupakan metode yang sudah dikenal dan banyak digunakan dalam menghadapi situasi MADM (multiple attribute decision making). MADM adalah suatu metode yang digunakan untuk mencari alternatif optimal dari sejumlah alternatif dengan kriteria tertentu (Masri, 2016). Metode SAW merupakan metode penjumlah bobot dari rating kinerja pada setiap alternatif dari semua kriteria (Mujiastuti, Komariyah and Hasbi, 2017). Gambar 1 menunjukkan bahwa metode SAW memiliki beberapa tahapan. 


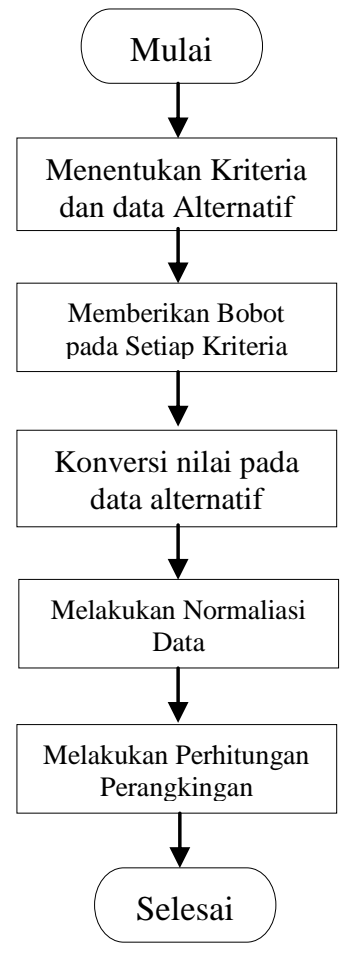

Gambar 1. Metode Simple Additive Weighting

1. Menentukan kriteria (Ci) dan data alternatif (Ai) Kriteria di sini diambil dari hasil pengumpulan data dengan menggunakan wawancara dan menghasilkan 6 kriteria, yaitu Kehadiran, Kerja sama, Komitmen, Kepemimpinan, ketepatan target Kerja, Sikap / Etika.

2. Memberikan bobot (W) pada setiap kriteria Setiap kriteria diberikan bobot penilaian yang mencapai 100.

3. Melakukan normalisasi (R) matriks keputusan Normalisasi dalam perhitungan penilaian kinerja karyawan, menggunakan rumus (1) dari (Loekito $d k k ., 2020)$.

$$
R_{i j}=\left\{\begin{array}{l}
\frac{x_{i j}}{\max x_{i j}} \text { jika } j \text { adalah atribut keuntungan (benefit) } \\
\frac{\min x_{i j}}{x_{i j}} \quad \text { jika } j \text { adalah atribut biaya (cost) }
\end{array}\right.
$$

Keterangan (1)

$\mathrm{r}_{\mathrm{ij}}=$ rating kinerja ter normalisasi

$\max _{\mathrm{ij}}=$ nilai maksimum dari setiap baris dan kolom $\min _{\mathrm{ij}}=$ nilai minimum dari setiap baris dan kolom $\mathrm{x}_{\mathrm{ij}}=$ baris dan kolom dari matriks

Pada rumus (1) $\mathrm{r}_{\mathrm{ij}}$ adalah rating kinerja ter normalisasi dari alternatif $\mathrm{Ai}$ pada atribut $\mathrm{Cj}$; $\mathrm{i}=$ $1,2, \ldots$, m sedangkan $\mathrm{j}=1,2, \ldots, \mathrm{n}$.

4. Melakukan pemeringkatan (Vi)

Untuk melakukan pemeringkatan, rumus (2) yang digunakan adalah sebagai berikut :

$$
V_{i}=\sum_{i=1}^{n} W_{j} R_{i j}
$$

Keterangan (2)

$\mathrm{V}_{\mathrm{i}}=$ nilai akhir dari alternatif

$\mathrm{W}_{\mathrm{j}}=$ bobot yang telah ditentukan

$\mathrm{R}_{\mathrm{ij}}=$ normalisasi matriks

Pada rumus (2) nilai Vi yang lebih besar mengindikasikan bahwa alternatif Ai lebih terpilih.

5. Hasil dari pemeringkatan

Hasil dari pemeringkatan merupakan tahapan terakhir dalam proses sistem pendukung keputusan penilaian kinerja karyawan.

\section{PEMBAHASAN}

Langkah - langkah pada metode penelitian dapat dilihat lebih lanjut sebagai berikut :

1. Menentukan data kriteria dan bobot kriteria

Data kriteria yang digunakan dalam pengambilan keputusan penilaian kinerja karyawan terdiri dari 6 kriteria yang didapat dari hasil wawancara, seperti yang terlihat pada tabel 1 .

Tabel 1. Data Kriteria

\begin{tabular}{|l|l|l|}
\hline Kode & \multicolumn{1}{|c|}{ Kriteria } & Keterangan \\
\hline C1 & Kehadiran & Benefit \\
\hline C2 & Kerja sama & Benefit \\
\hline C3 & Komitmen & Benefit \\
\hline C4 & Kepemimpinan & Benefit \\
\hline C5 & $\begin{array}{l}\text { Ketepatan Target } \\
\text { Kerja }\end{array}$ & Benefit \\
\hline C6 & Sikap / Etika & Benefit \\
\hline
\end{tabular}

Kriteria pada penilaian kinerja karyawan ini, meliputi:

1. Kriteria Kehadiran

Kriteria ini didapatkan berdasarkan perhitungan rekapitulasi kehadiran karyawan

2. Kriteria Kerja sama

Kriteria ini didapatkan berdasarkan penyelesaian pekerjaan yang dikerjakan secara tim

3. Kriteria Komitmen

Kriteria ini didapatkan berdasarkan sikap tanggung jawab karyawan dalam menyelesaikan pekerjaan

4. Kriteria Kepemimpinan

Kriteria ini didapatkan berdasarkan penilaian dari sifat seorang kepala regu dan masing - masing karyawan

5. Kriteria Ketepatan target Kerja

Kriteria ini didapatkan berdasarkan hasil kerja karyawan dengan ketepatan target pekerjaan yang telah ditentukan pada setiap bagian dan diberikan nilai langsung oleh masing - masing manager pada setiap bagian. 
6. Kriteria Sikap / Etika

Kriteria ini didapat dari sikap atau etika karyawan kepada rekan kerja atau kepada atasan

Pada tabel 2, merupakan daftar batas data dan konversi nilai pada setiap kriteria yang digunakan pada penelitian ini.

Tabel 2. Data Konversi Nilai Kriteria Kehadiran

\begin{tabular}{|c|c|c|}
\hline Kriteria & Batas & Nilai \\
\hline \multirow[t]{4}{*}{ Kehadiran } & $<=70 \%$ & 1 \\
\hline & $>70 \%$ dan $<=80 \%$ & 2 \\
\hline & $>80 \%$ dan $<=90 \%$ & 3 \\
\hline & $>90 \%$ dan $100 \%$ & 4 \\
\hline \multirow[t]{4}{*}{ Kerja sama } & Tidak baik & 1 \\
\hline & Cukup baik & 2 \\
\hline & Baik & 3 \\
\hline & Sangat baik & 4 \\
\hline \multirow[t]{4}{*}{ Komitmen } & Tidak baik & 1 \\
\hline & Cukup baik & 2 \\
\hline & Baik & 3 \\
\hline & Sangat baik & 4 \\
\hline \multirow[t]{4}{*}{ Kepemimpinan } & Tidak baik & 1 \\
\hline & Cukup baik & 2 \\
\hline & Baik & 3 \\
\hline & Sangat baik & 4 \\
\hline \multirow{4}{*}{$\begin{array}{l}\text { Ketepatan Target } \\
\text { Kerja }\end{array}$} & Tidak baik & 1 \\
\hline & Cukup baik & 2 \\
\hline & Baik & 3 \\
\hline & Sangat baik & 4 \\
\hline \multirow[t]{4}{*}{ Sikap / Etika } & SP3 & 1 \\
\hline & SP2 & 2 \\
\hline & SP1 & 3 \\
\hline & Tidak ada SP & 4 \\
\hline
\end{tabular}

2. Memberikan bobot pada setiap kriteria

Langkah selanjutnya adalah pemberian bobot pada Setiap kriteria. Dapat dilihat pada tabel 3 bahwa setiap kriteria diberi bobot sesuai dengan tingkat kepentingannya total bobot yang digunakan mencapai 100.

Tabel 3. Data Bobot pada Setiap Kriteria

\begin{tabular}{|l|l|c|}
\hline Kode & \multicolumn{1}{|c|}{ Kriteria } & Bobot \\
\hline C1 & Absensi & 20 \\
\hline C2 & Kerja sama & 20 \\
\hline C3 & Komitmen & 15 \\
\hline C4 & Kepemimpinan & 20 \\
\hline C5 & Ketepatan Target Kerja & 15 \\
\hline C6 & Sikap / Etika & 10 \\
\hline
\end{tabular}

Pengumpulan data awal pada penelitian ini adalah hal yang penting. Data awal ini diperoleh dari pihak perusahaan yang berupa sampel karyawan yang berjumlah 10 beserta nilai dari setiap kriteria yang digunakan dalam hal penilaian karyawan dan data awal dapat dilihat pada tabel 4 .
Tabel 4. Data Awal

\begin{tabular}{|l|l|l|l|l|l|l|}
\hline Data & C1 & C2 & C3 & C4 & C5 & C6 \\
\hline RP & $85 \%$ & CK & SB & B & TB & TB \\
\hline NH & $70 \%$ & SB & B & SB & CK & CK \\
\hline PT & $65 \%$ & CK & B & SB & B & SB \\
\hline HK & $80 \%$ & CK & SB & B & B & B \\
\hline DS & $85 \%$ & CK & B & B & SB & SB \\
\hline IF & $70 \%$ & B & SB & B & B & B \\
\hline CP & $75 \%$ & B & SB & B & B & CK \\
\hline YE & $60 \%$ & TB & B & B & CK & B \\
\hline EP & $80 \%$ & TB & B & B & SB & CK \\
\hline NH & $80 \%$ & B & SB & B & CK & B \\
\hline
\end{tabular}

Langkah selanjutnya adalah mengubah nilai pada data awal pada tabel 4 ke dalam data alternatif dengan melihat nilai konversi pada setiap kriteria dapat dilihat pada tabel 5 .

Tabel 5. Data Alternatif

\begin{tabular}{|l|l|l|l|l|l|l|}
\hline Data & C1 & C2 & C3 & C4 & C5 & C6 \\
\hline A1 & 3 & 2 & 4 & 3 & 1 & 1 \\
\hline A2 & 1 & 4 & 3 & 4 & 2 & 2 \\
\hline A3 & 1 & 2 & 3 & 4 & 3 & 4 \\
\hline A4 & 3 & 2 & 4 & 3 & 3 & 3 \\
\hline A5 & 3 & 2 & 3 & 3 & 4 & 4 \\
\hline A6 & 1 & 3 & 4 & 3 & 3 & 3 \\
\hline A7 & 2 & 3 & 4 & 3 & 3 & 2 \\
\hline A8 & 1 & 1 & 3 & 3 & 2 & 3 \\
\hline A9 & 2 & 1 & 3 & 3 & 4 & 2 \\
\hline A10 & 2 & 3 & 4 & 3 & 2 & 3 \\
\hline
\end{tabular}

3. Normalisasi Data

Untuk kriteria C1 karena benefit maka dicari adalah nilai max dari $(3,1,1,3,3,1,2,1,2,2)$ adalah 3 didapatkan normalisasi berikut:

$$
\begin{gathered}
A 1=\frac{3}{\max 3113312122}=\frac{3}{3}=1 \\
A 2=\frac{1}{\max 3113312122}=\frac{1}{3}=0,33 \\
A 3=\frac{1}{\max 3113312122}=\frac{1}{3}=0,33 \\
A 4=\frac{3}{\max 3113312122}=\frac{3}{3}=1 \\
A 5=\frac{3}{\max 3113312122}=\frac{3}{3}=1 \\
A 6=\frac{1}{\max 3113312122}=\frac{1}{3}=0,33 \\
A 7=\frac{2}{\max 3113312122}=\frac{2}{3}=0,67 \\
A 8=\frac{1}{\max 3113312122}=\frac{1}{3}=0,33 \\
A 9=\frac{2}{\max 3113312122}=\frac{2}{3}=0,67 \\
A 10=\frac{2}{\max 3113312122}=\frac{2}{3}=0,67
\end{gathered}
$$


Untuk kriteria C2 karena benefit maka dicari adalah nilai max dari $(2,4,2,2,2,3,3,1,1,3)$ adalah 4 , didapatkan normalisasi berikut:

$$
\begin{gathered}
A 1=\frac{2}{\max 242223113}=\frac{2}{4}=0,5 \\
A 2=\frac{4}{\max 242233113}=\frac{4}{4}=1 \\
A 3=\frac{2}{\max 242233113}=\frac{2}{4}=0,5 \\
A 4=\frac{2}{\max 2422233113}=\frac{2}{4}=0,5 \\
A 5=\frac{2}{\max 242223313}=\frac{2}{4}=0,5 \\
A 6=\frac{3}{\max 2422233113}=\frac{3}{4}=0,75 \\
A 7=\frac{3}{\max 2422233113}=\frac{3}{4}=0,75 \\
A 8=\frac{1}{\max 2422233113}=\frac{1}{4}=0,25 \\
A 9=\frac{1}{\max 2422233113}=\frac{1}{4}=0,25 \\
A 10=\frac{3}{\max 242223113}=\frac{3}{4}=0,75
\end{gathered}
$$

Untuk kriteria C3 karena benefit maka dicari adalah nilai max dari $(4,3,3,4,3,4,4,3,3,4)$ adalah 4 , didapatkan normalisasi:

$$
\begin{gathered}
A 1=\frac{4}{\max 4334344334}=\frac{4}{4}=1 \\
A 2=\frac{3}{\max 434344334}=\frac{3}{4}=0,75 \\
A 3=\frac{3}{\max 4334344334}=\frac{3}{4}=0,75 \\
A 4=\frac{4}{\max 4334344334}=\frac{4}{4}=1 \\
A 5=\frac{3}{\max 4334344334}=\frac{3}{4}=0,75 \\
A 6=\frac{4}{\max 4334344334}=\frac{4}{4}=1 \\
A 7=\frac{4}{\max 4334344334}=\frac{4}{4}=1 \\
A 8=\frac{3}{\max 4334344334}=\frac{3}{4}=0,75 \\
A 9=\frac{3}{\max 4334344334}=\frac{3}{4}=0,75 \\
A 10=\frac{4}{\max 4334344334}=\frac{4}{4}=1
\end{gathered}
$$

Untuk kriteria C4 karena benefit maka dicari adalah nilai max dari $(3,4,4,3,3,3,3,3,3,3)$ adalah 4 , didapatkan normalisasi:

$$
\begin{gathered}
A 1=\frac{3}{\max 344333333}=\frac{3}{4}=0,75 \\
A 2=\frac{4}{\max 34433333}=\frac{4}{4}=1 \\
A 3=\frac{4}{\max 34433333}=\frac{4}{4}=1 \\
A 4=\frac{3}{\max 344333333}=\frac{3}{4}=0,75 \\
A 5=\frac{3}{\max 344333333}=\frac{3}{4}=0,75 \\
A 6=\frac{3}{\max 3443333333}=\frac{3}{4}=0,75 \\
A 7=\frac{3}{\max 3443333333}=\frac{3}{4}=0,75 \\
A 8=\frac{3}{\max 3443333333}=\frac{3}{4}=0,75 \\
A 9=\frac{3}{\max 3443333333}=\frac{3}{4}=0,75 \\
A 10=\frac{3}{\max 3443333333}=\frac{3}{4}=0,75
\end{gathered}
$$

Untuk kriteria C5 karena benefit maka dicari adalah nilai max dari $(1,2,3,3,4,3,3,2,4,2)$ adalah 4 , didapatkan normalisasi:

$$
\begin{gathered}
A 1=\frac{1}{\max 1233433242}=\frac{1}{4}=0,25 \\
A 2=\frac{2}{\max 123343242}=\frac{2}{4}=0,5 \\
A 3=\frac{3}{\max 1233433242}=\frac{3}{4}=0,75 \\
A 4=\frac{3}{\max 1233433242}=\frac{3}{4}=0,75 \\
A 5=\frac{4}{\max 1233433242}=\frac{4}{4}=1 \\
A 6=\frac{3}{\max 1233433242}=\frac{3}{4}=0,75 \\
A 7=\frac{3}{\max 1233433242}=\frac{3}{4}=0,75 \\
A 8=\frac{2}{\max 1233433242}=\frac{2}{4}=0,5 \\
A 9=\frac{4}{\max 1233433242}=\frac{4}{4}=1 \\
A 10=\frac{2}{\max 1233433242}=\frac{2}{4}=0,5
\end{gathered}
$$

Untuk kriteria C6 karena benefit maka dicari adalah nilai max dari $(1,2,4,3,4,3,2,3,2,3)$ adalah 4 , didapatkan normalisasi: 


$$
\begin{aligned}
A 1 & =\frac{1}{\max 1243432323}=\frac{1}{4}=0,25 \\
A 2 & =\frac{2}{\max 1243432323}=\frac{2}{4}=0,5 \\
A 3 & =\frac{4}{\max 1243432323}=\frac{4}{4}=1 \\
A 4 & =\frac{3}{\max 1243432323}=\frac{3}{4}=0,75 \\
A 5 & =\frac{4}{\max 1243432323}=\frac{4}{4}=1 \\
A 6 & =\frac{3}{\max 1243432323}=\frac{3}{4}=0,75 \\
A 7 & =\frac{3}{\max 1243432323}=\frac{2}{4}=0,5 \\
A 8 & =\frac{3}{\max 1243432323}=\frac{3}{4}=0,75 \\
A 9 & =\frac{3}{\max 1243432323}=\frac{2}{4}=0,5 \\
A 10 & =\frac{3}{\max 1243432323}=\frac{3}{4}=0,75
\end{aligned}
$$

Tahapan selanjutnya adalah normalisasi data, dapat dilihat pada tabel 6 semua nilai alternatif di normalisasi.

\section{Tabel 6. Data Normalisasi}

\begin{tabular}{|l|l|l|l|l|l|l|}
\hline Data & C1 & C2 & C3 & C4 & C5 & C6 \\
\hline A1 & 1 & 0,5 & 1 & 0,75 & 0,25 & 0,25 \\
\hline A2 & 0,33 & 1 & 0,75 & 1 & 0,5 & 0,5 \\
\hline A3 & 0,33 & 0,5 & 0,75 & 1 & 0,75 & 1 \\
\hline A4 & 1 & 0,5 & 1 & 0,75 & 0,75 & 0,75 \\
\hline A5 & 0,33 & 0,5 & 0,75 & 0.75 & 1 & 1 \\
\hline A6 & 0,33 & 0,75 & 0,75 & 0,75 & 0,75 & 0,75 \\
\hline A7 & 0,67 & 0,75 & 1 & 0,75 & 0,75 & 0,5 \\
\hline A8 & 0,33 & 0,25 & 0,75 & 0,75 & 0,5 & 0,75 \\
\hline A9 & 0,67 & 0,25 & 0,75 & 0,75 & 1 & 0,5 \\
\hline A10 & 0,67 & 0,75 & 1 & 0,75 & 0,5 & 0,75 \\
\hline
\end{tabular}

4. Pemeringkatan

Dalam melakukan Pemeringkatan, dilakukan perkalian pada bobot kriteria dengan setiap hasil dari normalisasi, berikut perhitungan penentuan pemeringkatan pada setiap alternatif:

$$
\begin{aligned}
\mathrm{A} 1= & (1 * 20)+(0,5 * 20)+(1 * 15)+(0,75 * 20)+ \\
& (0,25 * 15)+(0,25 * 10)=66,25 \\
\mathrm{~A} 2= & (0,33 * 20)+(1 * 20)+(0,75 * 15)+(1 * 20)+ \\
& (0,5 * 15)+(0,5 * 10)=70,35 \\
\mathrm{~A} 3= & (0,33 * 20)+(0,5 * 20)+(0,75 * 15)+(1 * 20)+ \\
& (0,75 * 15)+(1 * 10)=69,1
\end{aligned}
$$

$$
\begin{aligned}
\mathrm{A} 5= & (0,33 * 20)+(0,5 * 20)+(0,75 * 15)+(0,33 * 20) \\
& +(1 * 15)+(1 * 10)=59,45 \\
\mathrm{~A} 6= & (0,33 * 20)+(0,75 * 20)+(0,75 * 15)+(0,75 * 20) \\
& +(0,75 * 15)+(0,75 * 10)=66,6 \\
\mathrm{~A} 7= & (0,67 * 20)+(0,75 * 20)+(1 * 15)+(0,75 * 20)+ \\
& (0,75 * 15)+(0,5 * 10)=74,65 \\
\mathrm{~A} 8= & (0,33 * 20)+(0,25 * 20)+(0,75 * 15)+(0,75 * 20) \\
& +(0,5 * 15)+(0,75 * 10)=52,85 \\
\mathrm{~A} 9= & (0,67 * 20)+(0,25 * 20)+(0,75 * 15)+(0,75 * 20) \\
& +(1 * 15)+(0,5 * 10)=64,65 \\
\mathrm{~A} 10= & (0,67 * 20)+(0,75 * 20)+(1 * 15)+(0,75 * 20)+ \\
& (0,5 * 15)+(0,75 * 10)=73,4
\end{aligned}
$$

Hasil Pemeringkatan dilakukan pada penelitian ini. Tabel 7 dapat dilihat bahwa metode SAW berhasil melakukan pemeringkatan dalam penilaian kinerja karyawan dan cepat menghasilkan nilainya dan diperoleh nilai tertinggi adalah 78.75 dan diperoleh nilai terendah adalah 52,85.

Tabel 7. Data Hasil Pemeringkatan

\begin{tabular}{|c|c|c|}
\hline Data Alternatif & Nilai & Peringkat \\
\hline A4 & 78,75 & 1 \\
\hline A7 & 74,65 & 2 \\
\hline A10 & 73,4 & 3 \\
\hline A2 & 70,35 & 4 \\
\hline A3 & 69,1 & 5 \\
\hline A6 & 66,6 & 6 \\
\hline A1 & 66,25 & 7 \\
\hline A9 & 64,65 & 8 \\
\hline A5 & 59,45 & 9 \\
\hline A8 & 52,85 & 10 \\
\hline
\end{tabular}

Berdasarkan data hasil pemeringkatan yang telah di dapat pada tabel 7, maka berdasarkan data awal pada tabel 4, nama-nama karyawan yang dijadikan data alternatif didapatkan peringkat 1 sampai 10 yaitu $\mathrm{HK}$, CP, DH, NH, PT, IF, RP, EP, DS, YE.

\section{KESIMPULAN}

Hasil dari penelitian ini adalah bahwa metode SAW telah berhasil melakukan pemeringkatan data penilaian kinerja karyawan. Dimana didapat nilai tertinggi pada perhitungan nilai adalah 78,75 dan nilai terendah adalah 52,85 , dengan nilai tersebut dapat dijadikan sebagai penentuan dalam pengambilan keputusan untuk karyawan terbaik dan karyawan yang mendapatkan perbaikan kinerja. 


\section{SARAN}

Saran dari penelitian ini adalah, dapat dilanjutkan dengan membuat aplikasi sistem pendukung keputusan berbasis web agar dapat mempermudah HRD dalam melakukan penilaian kinerja karyawan dan semua karyawan juga dapat melihat nilai yang diperoleh secara transparan. Penelitian selanjutnya dapat dilakukan perbandingan antara metode SAW dengan metode lain untuk mendapatkan hasil yang lebih maksimal lagi dalam proses pemeringkatan.

\section{DAFTAR PUSTAKA}

Achmad, Y. F., \& Laday, R. K. 2018. Sistem Pendukung Keputusan dalam Penentuan Lulusan Terbaik menggunakan Metode Weighted Product (Studi Kasus: Institut Sains dan Teknologi AlKamal Jakarta). In Seminar Nasional Teknologi Informasi dan Komunikasi (SEMNASTIK) (Vol. 1, No. 1, pp. 196-202)..

Anto, A. G., Mustafidah, H. dan Suyadi, A. 2015. 'Sistem Pendukung Keputusan Penilaian Kinerja Karyawan Menggunakan Metode SAW (simple additive weighting) di Universitas Muhammadiyah Purwokerto', JUITA, III(4), pp. 193-200.

Hardianti, M., Hidayatullah, R., Pratiwi, F., \& Hadiansa, A. (2017). Sistem Penunjang Keputusan Penilaian Kinerja Pegawai Menggunakan Metode Analytical Hierarchy Process (Ahp). Informatika, 9(2), 70-77.

Loekito, L. H. 2020. Penerapan Sistem Pendukung Keputusan Penilaian Kinerja Pegawai Menggunakan Metode Simple Additive
Weighting (SAW) pada universitas XYZ. Jurnal ilmu komputer indonesia, 5(1), 6-12.

Masri, M. 2016 'Penentuan Karyawan Terbaik Dengan Metode Simple Additive Weighting (PDAM Tirta Silaupiasa)', JET (Journal of Electrical Technology), 1(1), pp. 36-41. Available at: https://jurnal.uisu.ac.id/index.php/jet/article/view $/ 187$.

Mujiastuti, R., 2017 'Sistem Penilaian Kinerja Karyawan Menggunakan Metode Simple Additive Weighting (SAW)', Jurnal Sistem Informasi, Teknologi Informasi dan Komputer, 9(2), pp. 133-141.

Ramesh. Delen Sharda (Dursun. Turban, Efraim.). 2020. Analytics, Data Science, \& Artificial Intelligence: Systems For Decision Support, Global Edition. Pearson Education Limited.

Sukanto, P. S. (2018) 'Sistem Pendukung Keputusan Penilaian Kinerja Karyawan Pt Harjamukti Jaya Mandiri Menggunakan Metode Simple Additive Weighting', JATISI (Jurnal Teknik Informatika dan Sistem Informasi), 5(1), pp. 109-118. doi: 10.35957/jatisi.v5i1.121.

Warmayudha, I. P. E. and Komarudin. 2017. 'Penilaian Kinerja Karyawan Di Itenas Dengan Menggunakan Metode Saw Berbasis Website', Repository Nusamandiri, 13(2), pp. 106-111. Available at: https://repository.nusamandiri.ac.id/index.php/re po/viewitem/6315.

Waskito, R. R., Setya, B. and Daryanto. 2018. 'Sistem Pendukung Keputusan Menggunakan Metode Simple Additive Weighting Pada Ptpn Xii Perkebunan Malangsari', 10, pp. 497-504. 